\title{
AUTOMATIC SMART-BIN WITH COMBINED UV ENABLED MICROWAVE BASED DISINFECTION OF HOSPITAL WASTE
}

\author{
Er. Manoj G S \\ Division of Clinical Engineering \\ SCTIMST, Kerala, Trivandrum, India
}

\author{
Dr. Manikandan S \\ Department of Anesthesia \\ SCTIMST, Kerala, Trivandrum, India
}

\author{
Er. Rahul G Nath \\ Division of Clinical Engineering \\ SCTIMST, Kerala, Trivandrum
}

\begin{abstract}
In view of the COVID-19 Pandemic, there is an unprecedented importance to the disinfection of the waste generated at the source itself. Normally wastes from the hospitalities are collected without proper dis-infection and are kept without any closure and treated after many days. This will lead to increased multiplication and transmission of viruses. The spreading of many infectious diseases, mainly due to corona virus is increasing day by day. Main factor for the spreading is that the waste materials that are handled by the infected person come in contact with the non-infectious surroundings. To avoid such a situation we are going to implement a project called automatic smart dustbin with Ultraviolet enabled microwave disinfection. Implementation is done with the help of microcontroller, UV lights, UV lamps and microwave generating system. Smart bins can be installed in hospitals, houses and all places where the waste can be deposited without touching the bin and deposited waste will undergo UV enabled microwave disinfection. Compared to other disinfection methods using ultra violet, the microwave disinfection technique is much better. The microwave method results in an average log reduction of 5.06 of viable virus, whereas an UV can reduce it to 4.86 . Keywords: Corona, Microwave, Ultraviolet
\end{abstract}

\section{INTRODUCTION}

The objective of the paper is to design and build a prototype for automatic open dust bin that can automatically open the lid when it detects the people who want to throw their trash and waste. The main disadvantages of the disinfection system available today in the field of hospitalities are :

1. At present, highly infectious materials are collected by open methods by healthcare workers and transferred to collection bins. The transferring, opening and closing are all done with hands leading to potential harm to health care workers as well as risk of transmission to other patients.

2. The wastes especially contaminated with secretions, body fluids are kept in the common bin in the wards and ICUs till the bin is full and then disposed. This process can also lead to spill over as well as keeping the highly dangerous material in the patient care area till disposal.

3. The transfer of biohazard and infectious material takes place from various wards and ICUs to designated areas within hospital where facility is available or to another area outside hospital if facility is not available especially in small hospitals, nursing homes, as well as field areas like ambulances, mobile units etc.

4. Nowadays available disinfection systems for face masks as well as the hospital wastes are only a surface disinfection system on which most of the UV systems carryout the disinfection of wastes at the direct contacted surface of light rays. It cannot carry out total penetration.

This paper introduces a combined system that undergoes UV enabled microwave disinfection after closing the lid of the bin for 2 minutes duration inside the specially covered collecting space of the bin. After the process the microwave and UV lights are automatically switched off and the lid gets closed. Whenever a waste material is detected in the bin the cycle continues automatically. Filled bin trashes are sealed to a cover without touching the system and can be collected directly outside the bin. The special mechanism used in this system ensures the safety as well as a hygiene of the environment. It would be advantageous and safer to collect and disinfect the various hospital wastes in the wards and ICU at the collection point and enable safe transport to places for disposal. Moreover the proposed technology can also be used outside hospital settings like mobile units, ambulances, isolation areas etc.

\section{PROPOSED SYSTEM}

Currently Ultraviolet rays and microwave based technology are becoming popular for disinfection. UV light is effective in disinfection of air, water etc. and is good for disinfecting surface. However the disadvantages are it can lead to skin cancer due to long term exposure. The penetrability of UV light is poor and not effective especially considering different hospital waste. (1) Microwave powered UV technology generates both microwave and UV waves to help in disinfection of materials. (2) The advantages of microwave are 
rapid disinfection, deeper penetration as well as high microbial reduction that can be achieved compared to UV light. (3) It is safe for human use. We are planning to incorporate microwave technology in our project.

It is a cost effective method for disinfection. When it detects the waste, it automatically opens the lid for collecting and undergoes disinfection after closing the lid.

- $\quad$ The viruses are disintegrated by differential heating and UV exposure in the range of 85 to 95 degree Celsius.

- It uses electrode less UV lamps which get energized by microwave in it.

- The time of sterilization is set for 90 seconds depending on the size and constituents of object.

- It weighs approximately $3 \mathrm{~kg}$ with $45 \mathrm{~cm} X 30 \mathrm{~cm} \times 35 \mathrm{~cm}$ dimensions having 18 litre capacities.

- It can be easily transported from one site to another with wheels connecting to it.

- $\quad$ Portable unit working with 230 voltage AC, takes power of 700 watts

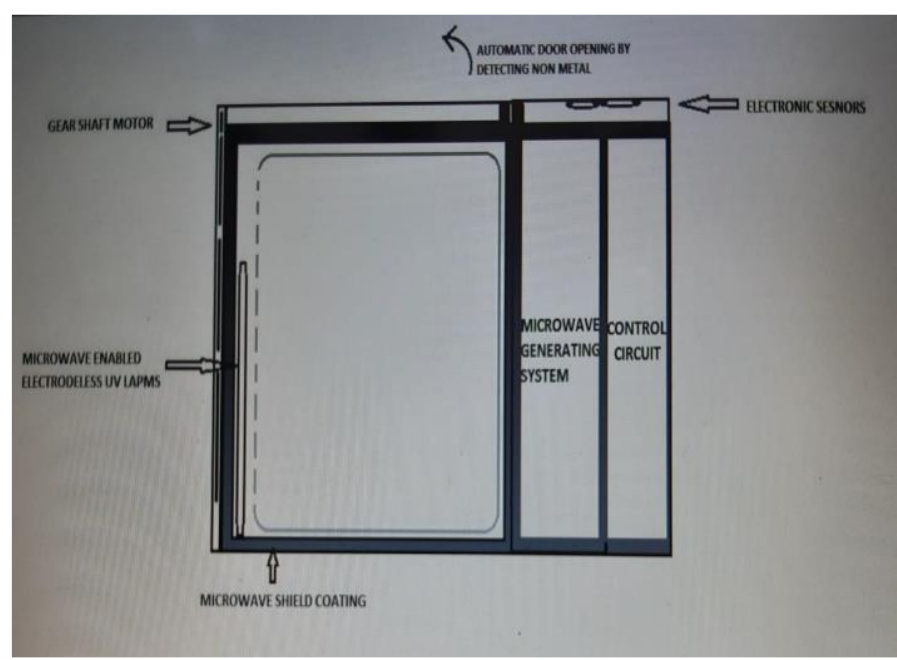

Fig. 1. Proposed Prototype

It has a closed cavity in which microwave and UV leakage are strictly bounded from escaping to the surroundings. Motion sensors (Ultrasonic sensors) attached to the system detects the presence of waste (or human presence) and send signal to the motor connected to the system through microcontroller (UNO). After opening the lid it collects all non-metallic wastes, it closes automatically after the pre-set delay and moves to the microwave generating through the signal to the system. Electrode less UV lamps attached opposite to the microwave generating parts get energized. Using that energy it get turned on. During that time the system gets off after the pre-set delay for the disinfection and it get on whenever a signal is getting from the sensor connected to it. When the bin gets full it can be collected the deposited waste from the separately fitted door in side of it.

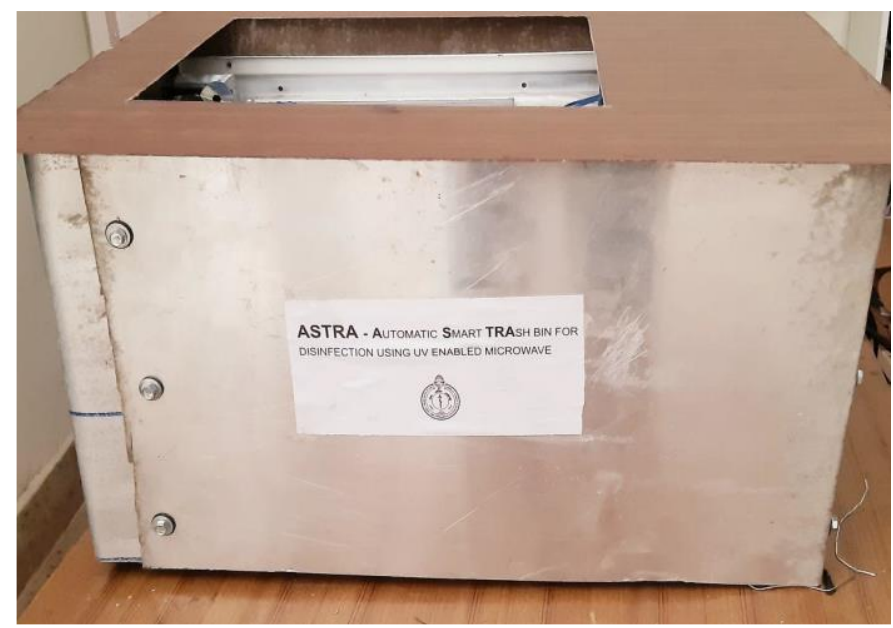

Fig. 2. Prototype of System

\section{EXPERIMENT AND RESULT}

The proposed system undergoes various clinical trials on the Microbiology Department of Sree Chitra Tirunal Institute of medical science and Technology (SCTIMST). It is done various clinical conditions to achieve the better result of microorganism disinfection in the system by Clinical experts. It is selected three kinds of sample for experiment. It puts in the system for various time and temperature settings

Fig -3 Experiment Result 
International Journal of Engineering Applied Sciences and Technology, 2020

Vol. 5, Issue 3, ISSN No. 2455-2143, Pages 607-610

Published Online July 2020 in IJEAST (http://www.ijeast.com)

\begin{tabular}{|c|c|c|}
\hline Staphylococcus.Aureus & $\begin{array}{l}\text { 40-70 degree } \\
\text { Celsius \& } 60 \\
\text { Seconds }\end{array}$ & $\begin{array}{c}\text { Growth } \\
\text { observed }\end{array}$ \\
\hline E. coli & $\begin{array}{l}40-70 \text { degree } \\
\text { Celsius \& } 60 \\
\text { Seconds }\end{array}$ & $\begin{array}{l}\text { Growth } \\
\text { observed }\end{array}$ \\
\hline Staphylococcus.Aureus & $\begin{array}{l}85 \text { degree } \\
\text { Celsius \& } 90 \\
\text { Seconds }\end{array}$ & $\begin{array}{l}\text { Growth } \\
\text { observed }\end{array}$ \\
\hline E. coli & $\begin{array}{l}85 \text { degree } \\
\text { Celsius\& } 90 \\
\text { seconds }\end{array}$ & $\begin{array}{l}\text { Growth } \\
\text { observed }\end{array}$ \\
\hline Staphylococcus. Aureus & $\begin{array}{l}95 \text { degree } \\
\text { Celsius\& } 60 \\
\text { seconds }\end{array}$ & $\begin{array}{l}\text { No Growth } \\
\text { Observed }\end{array}$ \\
\hline E. coli & $\begin{array}{l}95 \text { degree } \\
\text { Celsius\& } 60 \\
\text { seconds }\end{array}$ & $\begin{array}{l}\text { No Growth } \\
\text { Observed }\end{array}$ \\
\hline
\end{tabular}

\section{CONCLUSION}

- Sample which is put on the microwave system assisted with $254 \mathrm{~nm}, 3$ watts UV bulb at 85 to 95 degree Celsius and an exposure time of 60 to 90 seconds suggests that there is no growth observed and its base for disinfection purposes.
- The device can easily disinfect all kind of hospital masks including the face masks and have the penetrating power to disinfect each side of the waste thereby totally killing the microorganisms compared to other disinfection systems including UV method.

- Proposed system can be used for disinfection of hospital waste thereby reducing the risk of waste collectors and the hazard of being storage of the wastes for a long time.

- This Device could be replicated with local resources and minimum material movement.

\section{ACKNOWLEDGEMENT}

We are indebted to Dr Kavita Raja and Dr Dinoop K.P for their excellent support for the clinical validation of the system in microwave-UV disinfection and the whole staff members of Division of clinical engineering, SCTIMST

\section{REFERENCES}

[1] Gardner, D.W.M. and Shama, G. (1998) the kinetics of Bacillus subtilize spore inactivation on later paper by UV light in combination with hydrogen peroxide. Journal of Applied Microbiology 84, 633 \pm 641 .

[2] 2. Gujjari, S K et al. Comparative evaluation of ultraviolet and microwave sanitization techniques for Tooth brush decontamina6on." Journal of International Society of Preventive \& Community Dentistry vol. 1, 1 (2011): 20-6.

[3] 3. F. Akşen, A. Kaya \& N. Akpolat (2004) Comparison of Bactericidal Ac6vity of Microwave, Ultraviolet and Disinfectant Solu6ons on Some Bacterial Strains, Biotechnology \& Biotechnological Equipment, 18:2, 122127.

[4] 4. Global, regional, and national life expectancy, all-cause mortality, and cause-specific mortality for 249 causes of death, 1980-2015: a systematic analysis for the Global Burden of Disease Study 2015.Lancet .388, 1459-1544 (2016).

[5] Centers for Disease Control and Prevention (CDC) (2008) Guideline for disinfection and sterilization in healthcare facilities. https://www.cdc.gov/infectioncontrol/guidelines /disinfection/index.html. Accessed June 2, 2020.

[6] Chang JC, Ossoff SF, Lobe DC, Dorfman MH, Dumais CM, Qualls RG, Johnson JD. UV inactivation of pathogenic and indicator microorganisms. Appl Environ Microbiol. 1985;49(6):1361-1365. doi: 10.1128/AEM.49.6.1361-1365.1985. [PMC free article] [PubMed] [CrossRef] [Google Scholar]

[7] Hijnen WA, Beerendonk EF, Medema GJ. Inactivation credit of UV radiation for viruses, bacteria and protozoan (oo) cysts in water: a review. Water Res. 2006;40(1):3- 
22. doi: 10.1016/j.watres.2005.10.030. [PubMed] [CrossRef] [Google Scholar]

[8] Indian Council of Medical research (ICMR) (2020) Guidance for evaluation of novel applications for COVID-19, ICMR, Department of Health Research. Accessed 30 May 2020.

[9] International Commission on Illumination (CIE) (2003) CIE 155:2003 ultraviolet air disinfection. https://files.cie.co.at/cie1552003\%2520(free\%2520copy\%2520March\%25202020).pd f. Accessed 2 Jun 2020.

[10] Malayeri AH, Mohseni M, Cairns B, Bolton JR, Chevrefils G, Caron E, Barbeau B, Wright H, Linden KG. Fluence (UV dose) required to achieve incremental log inactivation of bacteria, protozoa, viruses and algae. IUVA News. 2016;18(3):4-6. [Google Scholar]

[11] Mourya DT, Yadav PD, Majumdar TD, Chauhan DS, Katoch VM. Establishment of biosafety level-3 (BSL-3) laboratory: important criteria to consider while designing, constructing, commissioning and operating the facility in Indian setting. Indian J Med Res. 2014;140(2):171. [PMC free article] [PubMed] [Google Scholar]

[12] NIOSH (1972) Criteria for a recommended standard: occupational exposure to ultraviolet radiation, DHHS (NIOSH) Publication Number 73-11009.

[13] NIOSH (1973) Ultraviolet radiation and the work environment, national institute for occupational safety and health, DHHS (NIOSH) Publication Number 73-11005.

[14] She RC, Chen D, Pak P, Armani DK, Schubert A, Armani AM (2020) Build-at-home UV-C disinfection system for healthcare settings. arXiv preprint http://arxiv/abs/2003.12916

[15] US Food and Drug Administration (FDA) (2020) Enforcement policy for sterilizers, disinfectant devices, and air purifiers during the coronavirus disease 2019 (COVID-19) Public Health Emergency, Guidance for Industry and Food and Drug Administration Staff. https://www.fda.gov/regulatory-information/searchfda-guidance-documents/enforcement-policy-sterilizersdisinfectant-devices-and-air-purifiers-during-coronavirusdisease. Accessed 2 Jun 2020.

[16] World Health Organization (2020) Cleaning and disinfection of environmental surfaces in the context of COVID-19, Interim guidance, 15 May 2020. World Health Organization.

[17] mei, "A DWT-Based Image Watermarking Algorithm", in Proceedings of the IEEE International Conference on Multimedia and Expo, pp. 429-432, 2001.

[18] C. Hsu and J. Wu, "Multi-resolution Watermarking for Digital Images", IEEE Transactions on Circuits and Systems- II, Vol. 45, No. 8, pp. 1097-1101, August 1998.
[19] R. Mehul, "Discrete Wavelet Transform Based Multiple Watermarking Scheme", in Proceedings of the 2003 IEEE TENCON, pp. 935-938, 2003. 